\title{
DETERMINANT DETECTION OF TRANSFER PRICING DECISIONS
}

\author{
Ardiani Ika Sulistyawati ${ }^{1}$, Aprih Santoso $^{2}$, Liana Rokhawati ${ }^{3}$ \\ ${ }^{1,2,3}$ Accounting Program, Economics Faculty, Semarang University, Jl. Soekarno Hatta Semarang, 50196, \\ Indonesia \\ ${ }^{2}$ Corresponding e-mail: aprihsantoso@usm.ac.id
}

\begin{abstract}
This study aims to verify and analyze the effect of tax minimization, tunneling incentive and bonus mechanisms against the decision of transfer pricing. The population in this study are all companies registered in the Indonesia Stock Exchange unless the moving company financial sector during the period 2015-2017. While the sampling process using a purposive sampling method and the sample obtained as many as 132 companies. Tax minimization proxied using ETR (effective tax rate), tunneling incentive proxied using the percentage of foreign ownership above 20\%, and a mechanism that is measured by the percentage of net profit in year t to the year $t$-1.This research is a quantitative research and data used in this research is secondary data obtained from the company's annual report in 2015-2017 sourced from www.idx.co.id. This study analyzes the data by using logistic regression with SPSS 23.0. The results of this study indicate that tax minimization variables influence the decision of transfer pricing. This study also shows that the tunneling incentive effect on transfer pricing decisions while the variable bonus mechanism does not affect the decision of transfer pricing. Keywords: transfer pricing; tax minimization; tunneling incentive; bonus mechanism JEL Classification: H25,H26
\end{abstract}

Article info:

Received 8 April 2020

Revised 8 April 2020

Accepted 8 April 2020

Available online 8 April 2020

\section{INTRODUCTION}

This phenomenon of globalization also causes companies to make their production processes in production departments. However, this will become more difficult if a company turns out to have various branches located not only in one country, but also in other countries and that is what is happening right now. Therefore, an activity called transfer pricing was carried out to determine the price (Cholse, 2011). Transfer pricing is a classic issue in the field of taxation, especially regarding international transactions carried out by multinational corporations. From the government side, transfer pricing is believed to result in reduced or loss of potential tax revenue of a country because multinational companies tend to shift their tax obligations from countries that have high tax rates to countries that apply low tax rates (Santoso, 2004). The practice of transfer pricing was previously only carried out by companies solely to assess the performance among members or divisions of the company but along with the times, the practice of transfer pricing is often also used for tax management, which is an attempt to minimize the amount of tax that must be paid (Mangoting, 2000).

The Taxation Law mentions the term transfer pricing with transactions between parties that have a special relationship. This is as regulated in article 18 paragraph (4) of Law number 36 of 2008 concerning Income Taxes. Transactions between parties that have a special relationship can result in the transfer of income, the basis of taxation or to manipulate the number of costs by the taxpayer. The Special relationship is the ownership relationship between one company and another company and this relationship occurs because the 
relationship or dependence of one party with another party that cannot be in a normal relationship, ownership or participation factors, the existence of control through management or use of technology, the existence of blood relations or because marriage is a major contributing factor to the emergence of a special relationship (Mangoting, 2000).

Tax dispute hearing between PT. Toyota Motor Manufacturing Indonesia (TMMIN) with the Director-General (Dirjen) of Taxes ended Monday afternoon (25/3). The panel of judges chaired by Sukma Alam closed the trial twelve times since last year. The tax dispute with the Japanese automotive company involves a large tax value and the process is quite tough. In the last session which was intended as a closing forum for both parties, there was even a heated debate between the two parties to attract the attention of the judges.

This dispute with TMMIN occurred because of a correction made by the DirectorGeneral of Taxes on the sale value and TMMIN royalty payments. This dispute revolved around the 2008 tax report. At that time, TMMIN's shareholders were Toyota Motor Corporation at $95 \%$ and the remaining 5\% was owned by PT. Astra International Tbk. In its tax report, TMMIN stated that the sales value reached Rp 32.9 trillion, but the Director General of Taxes corrected the value to $\mathrm{Rp} 34.5$ trillion or there was a correction of $\mathrm{Rp} 1.5$ trillion. With a correction value of Rp 1.5 trillion, TMMIN must add tax payments of Rp 500 billion. Before 2003, the Toyota Astra car assembly was still combined with the distribution section under the Toyota Astra Motor (TAM) banner. But after 2003, the assembly section was separated by the TMMIN flag while the distribution and marketing sections were under the TAM flag. The cars produced by TMMIN are sold first to TAM, then from TAM sold to Auto 2000. From Auto 2000, the cars are sold to consumers. Tax officials suspect that TMMIN's profit before tax decreased after 2003 due to royalty payments and improper raw material purchases. Other causes of car sales to affiliated parties such as TAM (Indonesia) and TMAP (Singapore) are below the cost of production, thereby reducing business circulation. In the inspection, the Directorate-General of Taxation highlighted the sale of Toyota Fortuner, Kijang Innova, and Toyota Dyna cars. In 2008, Fortuner type G was sold to TAM for Rp. 166 million per unit or $4 \%$ below the cost of production. While from TAM to Auto 2000 it was Rp. 252 million or with a profit margin of $50 \%$. This price is not yet a price that applies to consumers.

Likewise, the Kijang Innova Gatic product is sold from TMMIN to TAM Rp. 108 million or $4 \%-5 \%$ below the basic price, while TAM sells to Auto $2000 \mathrm{Rp}$. 141 million or has a margin of $30 \%$. "The low price of TMMIN also reduces state revenue through the Sales Tax on Luxury Goods," Amin said. According to Edward Hamonangan Sianipar, the tax apparatus, the separation of the two companies should not have an impact on the reduction in gross profit (gross margin) or net margin.

According to research Yuniasih et al., (2012) found that tax affects the transfer pricing decision. Increasing tax burden triggers companies to do transfer pricing in the hope that they can reduce the burden. According to Hartati and Julita (2015), tunneling incentive is a behavior of the majority shareholders who transfer the assets and profits of the company for their benefit, but minority shareholders also bear the costs they charge. Research on tunneling incentives has been carried out by Yuniasih et al., (2012) who found that tunneling incentives have a positive effect on manufacturing company decisions in transfer pricing.

According to Hartati dan Julita (2015), when bonuses are based on profits, it is logical that directors try to take action to regulate and manipulate profits to maximize the bonuses and remuneration they receive. In a bonus contract, two terms are known, namely bogey (the lowest level of profit to get a bonus) and a stamp (the highest level of profit). If the profit is below the bogey, there is no bonus received by the manager whereas if the profit is above the stamp, the manager will not get an additional bonus. If net income is below the bogey, managers tend to reduce profits, so too if profits are above the stamp. So only if the net profit 
is between bogey and cap, the manager will try to increase the company's net profit (Utomo, 2011). This study examines whether tax minimization, tunneling incentives, and bonus mechanisms influence on transfer pricing?

\section{LITERATURE REVIEWS}

Agency theory. On perspective of agency theory, the principal (owner or top management) supervises the agent (lower employee or manager) to carry out efficient performance. This theory assumes efficient performance and organizational performance is determined by the effort and influence of environmental conditions. In general, this theory assumes that the principal is neutral towards risk while the agent is resisting effort and risk. The agent and principal are motivated by their interests, and often the interests between the two clash (Lubis, 2010). Hartati and Julita (2015) explain that what is meant by agency theory is a theory that states that there are differences in interests between shareholders (shareholders), directors (company professionals) and company employees. and then it will cause a conflict between individual interests and the interests of the company. Agency problems arise due to opportunistic actions taken by managers to prosper their interests that are contrary to the interests of shareholders (principal). Mispiyanti (2015), Agency theory can imply the existence of information asymmetry. Conflicts between groups or agency conflicts are conflicts that arise between owners, and company managers where there is a tendency for managers to prioritize individual goals rather than company goals. Furthermore, Mispiyanti (2015), states several factors that can cause agency problems, namely moral hazard, time horizon problem, and managerial risk avoidance. Moral Hazard generally occurs in large companies (high complexity) where a manager does an activity that is not entirely known by shareholders or lenders. Income retention (earnings retention) as the problem revolves around the tendency to over-invest by the management (agent) through enhancement and growth with the aim to increase power, prestige, or appreciation, but can destroy the welfare of shareholders. Problems or time horizon conflicts arise as a result of cash flow conditions in which the principal places more emphasis on cash flows for the future whose conditions are uncertain. Management tends to emphasize matters relating to their work, the problem of managerial risk avoidance of the performance achieved, so that managers will try to minimize the risk of company stock from investment decisions that increase the risk. From the explanation above can lead to what is called agency cost, which according to this theory must be issued in such a way that the costs to reduce losses arising from non-compliance, resulting in adverse selection is where managers know more about the prospects of the company than outsiders. Principals can also limit their interests by providing an appropriate level of incentives to agents and are willing to pay monitoring costs to prevent hazards from agents.

Transfer pricing. Transfer pricing is the price contained in a product or service from one division to another in the same company or between companies that have a special relationship (Yuniasih et. al., 2012). Mangoting (2000) in Marfuah and Azizah (2014) in transactions that occur in a corporate environment such as this will make it difficult to determine the price that must be transferred. Pricing for various transactions between members or divisions is commonly referred to as transfer pricing. Understanding of special relationships based on the statement of Financial Accounting Standards (PSAK) number 7 Regarding the Disclosures of Parties having Special Relationships, the following definitions are given: Parties with Special Relationships are parties that are considered to have special relations if one party can control the other party or has significant influence over the other party in making financial and operational decisions. Transactions between parties having a Special Relationship are a transfer of resources or obligations between parties who have a special relationship, regardless of whether a price is calculated. Included as parties that have 
special relationships are companies under the control of one or more intermediaries, associated companies; individuals who have influential voting rights, and close family members; key employees; and companies owned directly or indirectly by anyone with significant influence. The definition of a special relationship according to the Income Tax Law number 36 of 2008 (PPh Law) is: "A special relationship is deemed to exist if: (a) the taxpayer has direct or indirect capital participation of at least $25 \%$ (twenty-five percent) in other taxpayers, or the relationship between the taxpayer and the participation a minimum of $25 \%$ (twenty-five percent) of two or more taxpayers, as well as the relationship between the last two or more taxpayers; or (b) the Taxpayer controls the other Taxpayers or two or more Taxpayers are under the same control either directly or indirectly or (c) There is a family relationship both blood and semenda in a straight line and or to one side".

Tax. According to Hartati and Julita (2015), "Tax is a state contribution owed by those who are required to pay it according to regulations, with no achievement being returned, which can be directly appointed, the duty of the state which runs the government". The tax has an important role in the life of the state especially in the implementation of development because taxes are a source of state revenue to finance all expenses including development financing. Based on the above according to Fathoni (2015) the tax has the following functions: (a) Budget Function, (b) Regulelated Function, (c) Stability Function, and (d) Equity Function (Distribution Function).

Tunneling incentive. Tunneling is the behavior of management or majority shareholders who transfer assets and profits of the company for their own interests, but the costs are charged to minority shareholders (Mutamimah, 2009). In a concentrated ownership structure, ownership is concentrated in control rights and cash-flow rights in certain parties as controlling shareholders (Mispiyanti, 2015). However, in developing countries like Indonesia and other Asian countries, a concentrated ownership structure that is generally dominated by founding families and the protection of weak minority shareholders creates agency conflict between majority shareholders and minority shareholders (Mutamimah, 2009). The ownership structure is believed to be able to influence the course of the company in achieving its goals, namely maximizing the value of the company (Wiranata and Nugrahanti, 2013). Yuniasih et al., (2012), in this ownership structure shareholders, are generally not willing to do the monitoring, because they have to bear all monitoring costs and only enjoy profits in proportion to their share ownership. So if all shareholders behave the same, then there will be no oversight of management. So the conclusion tunneling incentive is a behavior of the majority shareholders who transfer assets and profits of the company for their benefit, but minority shareholders must also bear the costs they charge.

Bonus mechanism. In carrying out their duties, directors tend to want to show good performance to company owners, because if the owner of the company or shareholders have assessed the performance of directors with a good rating, then the company owner will give awards to directors who have managed their companies well (Hartati and Julita, 2015). Companies usually use bonuses to improve employee performance, so that the profit generated annually becomes higher. Bonuses are payments at the same time given because they meet the company's performance goals. bonuses given by companies can be in the form of benefits, commissions, sales incentives, or employee welfare (Mispiyanti, 2015). The maximum bonus amount that can be paid to managers depends on the percentage of achievement of operating profit before interest costs and depreciation, operating profit before interest costs and net profit both to the realization of last year and its budget and health level multiplied by the adjustment factor. Since bonus schemes based on earnings are the most popular way of rewarding managers, it is logical for managers to manipulate earnings to maximize their income (Utomo, 2011). So in conclusion, the bonus mechanism 
is a calculation strategy in accounting that aims to reward the directors by looking at overall performance and profits.

The relationship between tax minimization to transfer pricing decisions. One reason companies do transfer pricing is tax minimization. Gusnardi (2009) states that multinational companies do transfer pricing to minimize tax obligations through price engineering that is transferred between divisions. Then according Hartati and Julita (2015), tax motivation in transfer pricing in multinational companies is carried out by moving income to the country with the lowest tax burden, where the country has a group of companies or divisions of companies that operate. Hartati and Julita(2015) found that transfers between large companies resulted in lower tax payments globally in general. The study found that multinational companies benefit because of a shift in income from high-tax to low-tax countries. Yuniasih et al., (2012), revealed that tax has a positive effect on transfer pricing decisions. Increasing tax burden triggers companies to do transfer pricing in the hope that they can reduce the burden. Because in business practices, entrepreneurs generally identify tax payments as an expense so that they will always try to minimize these costs to optimize profits. Based on the above formula, the hypothesis in this study is as follows.

\section{$H_{1}$ : Tax minimization affects transfer pricing decisions.}

The relationship between tunneling incentive to transfer pricing decisions. According to Yunasih et al., (2012) Ownership Structure reflects the type of agency conflict that occurs. There are 2 types of ownership structures, namely the dispersed ownership structure and the concentrated ownership structure. If all shareholders behave in the same way, there will be no oversight of management. Yuniasih et al., (2012) also found that tunneling incentives had a positive effect on the company's decision to transfer pricing. This is because related party transactions are more commonly used for wealth transfer purposes rather than dividend payments because listed companies must distribute dividends to parent companies and other minority shareholders. According to Hartati and Julita (2015) Tunneling is the behavior of management or majority shareholders who transfer assets and profits of the company for their interests, but the costs are charged to minority shareholders. We can simply imagine if the shareholders have large ownership, in other words they have also invested a large amount of capital in the company. So automatically they want a large return or dividend as well. For this reason, when the dividends distributed by the company must be shared with minority shareholders, the majority shareholder prefers to transfer pricing by transferring the company's wealth to its interests rather than dividing the dividends to the minority shareholders. Therefore, greater the ownership of shareholders then more triggering the practice of transfer pricing (Hartati and Julita, 2015). Based on the above formula, the hypothesis in this study is as follows.

$\mathrm{H}_{2}$ : Tunneling incentive affects transfer pricing decisions.

The relationship between bonus mechanism to transfer pricing decision. In carrying out their duties, the directors tend to want to show good performance to the owner of the company. Because if the owner of the company or the shareholders have assessed the performance of the directors with a good rating, the company owner will give awards to directors who have managed the company well. The award can be in the form of a bonus given to company directors. In giving bonuses to directors, company owners will see the performance of directors in managing their companies. Company owners in assessing the performance of directors usually see the overall company profits generated (Hartati and Julita, 2015). So the owner not only gives bonuses to directors who succeed in generating profits for their divisions or subunits, but also to directors who are willing to work together for the good and profit of the company as a whole. This is supported by the opinion of Hartati and Julita (2015) which states that compensation (bonus) directors are seen from the 
performance of various divisions or teams in one organization. The greater the company's overall profits generated, the better the image of the directors in the eyes of the company owner. Therefore, directors can do everything they can to maximize the company's profit including the practice of transfer pricing. In addition, Hartati et al., (2014) in his research also stated that company owners will see the company's profits generated as a whole as an assessment for the performance of its directors so that the directors will try as much as possible so that overall corporate profits have increased including by carrying out transfer pricing practices. Based on the above formula, the hypothesis in this study is as follows: $H_{3}$ : Bonus mechanism affects transfer pricing decision.

\section{Research Framework}

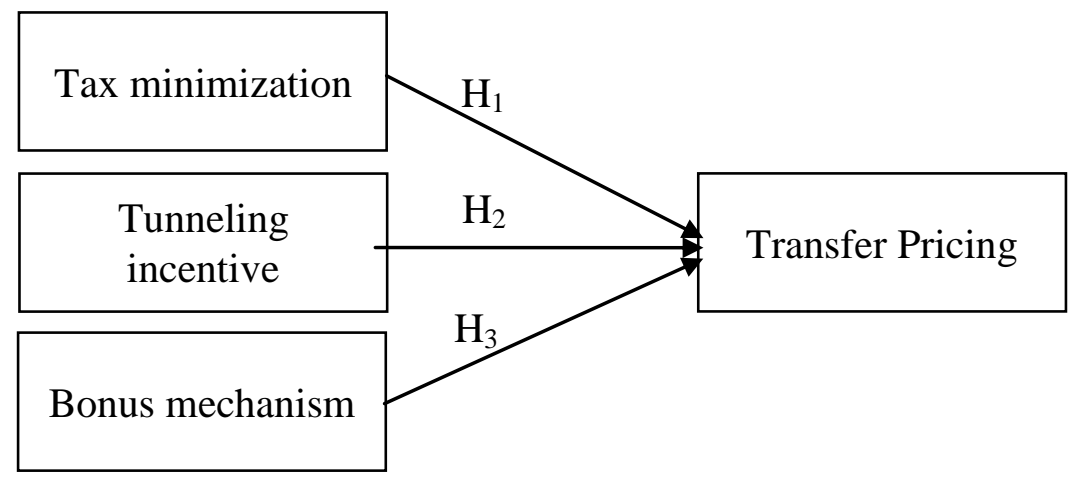

\section{RESEARCH METHOD}

The population of this study is all companies listing on the Indonesia Stock Exchange engaged in the financial sector in the period 2015-2017. Determination of the sample using a purposive sampling method with the following criteria:

\begin{tabular}{lr}
\hline \multicolumn{1}{c}{ Criteria } & Amount \\
\hline All companies listed on the Indonesia Stock Exchange during the period 2015-2017 & 523 \\
Financial sector companies & -81 \\
Sample company financial statements are not available for the 2015-2017 & -18 \\
Companies that do not have a foreign shareholding <20\% & -254 \\
Companies that suffered losses during the 2015-2017 observation period & -65 \\
Companies that do not present annual reports in one type of rupiah & -61 \\
\hline Number & 44 \\
\hline Sample 3 years & 132 \\
\hline
\end{tabular}

The sample used in this study was 132 observations of all non-financial companies. Descriptive statistics show that special relationship transactions occur at 83 observations, which means that most companies carry out transfer pricing. This research uses secondary data types (public company financial statements for the period 2015-2017) sourced from the website www.idx.co.id (Indonesia Stock Exchange website), journals and other sources. The data collection method is using the documentation method. This study uses a logistic regression analysis method with the SPSS 23.0 computer application program. Some statistical tests are used to assess overall fit model, namely value Log likelihood, Cox dan Snell's $R$ Square, Hosmer and Lemeshow's Goodness of Fit Test, classification table. The multiple linear regression equation in this study are: 


$$
\operatorname{Ln} \frac{\mathrm{TP}}{1-\mathrm{TP}}=\alpha+\beta_{1} \text { TAX }+\beta_{2} \text { TUNNELING }+\beta_{3} \text { BONUS }+\varepsilon_{\mathrm{i}}
$$

where,

Ln $\frac{T P}{1-T P} \quad$ is transfer pricing

$\begin{array}{lrl}\text { A } & \text { is } & \text { constant } \\ \text { B } & \text { is } & \text { slope or regression coefficient } \\ \text { TAX } & \text { is } & \text { tax minimization } \\ \text { TUNNELING is } & \text { tunneling incentive } \\ \text { BONUS } & \text { is } & \text { bonus mechanism } \\ \varepsilon_{\mathrm{i}} & \text { is } & \text { error observation }\end{array}$

\section{RESULTS AND DISCUSSIONS}

\subsection{Results}

Descriptive data analysis results. The initial step of this research is to describe the condition of each variable in the form of descriptive statistics. Table 1 presents the description of transfer pricing, tax minimization, tunneling incentives and bonus mechanisms.

Table 1. Descriptive Statistics

\begin{tabular}{llrrrr}
\hline & N & \multicolumn{1}{c}{ Minimum } & \multicolumn{1}{c}{ Maximum } & \multicolumn{1}{c}{ Mean } & \multicolumn{1}{c}{ Std. Deviation } \\
\hline Tax & 132 & -0.0030 & 0.9075 & 0.215566 & 0.1449383 \\
Tunneling & 132 & 21.7000 & 99.0800 & 57.283702 & 22.6155673 \\
Bonus & 132 & 0.0000 & 1.0000 & 0.560606 & 0.4982040 \\
Tpricing & 132 & 0.0000 & 1.0000 & 0.621212 & 0.4869331 \\
Valid N (listwise) & 132 & & & & \\
\hline
\end{tabular}

Based on the Table 1, it can be seen that from 132 data, there is an explanation as follows:

1. Tax minimization (Tax) which is proxied by ETR (effective tax rate) shows minimum values of -0.0030 and a maximum of 0.9075 , while the average tax minimization is 0.215566 with a standard deviation of 0.1449383 .

2. Tunneling incentive (Tunneling) which is proxied with a percentage of foreign share ownership above $20 \%$ shows that the minimum value is 21.7000 and the maximum value is $99.0800 \mathrm{~m}$ while the average value of Tunneling Incentive is 57.283702 with a standard deviation of 22.6155673 .

3. The bonus mechanism shows a minimum value of 0.0000 and a maximum of 1.0000 , while the average value of the bonus mechanism is 0.560606 with a standard deviation of 0.4982040 .

4. Transfer pricing (Pricing) shows a minimum value of 0.0000 and a maximum value of 1,0000 the average value of transfer pricing is 0.621212 with a standard deviation of 0.4869331 .

\subsection{Discussion}

Logistic regression analysis. Hypothesis testing in this study will be carried out using a logistic regression analysis model. The use of logistic regression analysis is because the dependent variable (transfer pricing) is in the form of dummy data, where this variable is a variable stated in value 1 to indicate the company that is doing transfer pricing and value 0 to indicate that the company did not transfer pricing. this is neither the need for testing of data normality nor the assumptions needed to justify the results of the study. Hypothesis testing 
with logistic regression analysis in this study was carried out with the help of the SPSS computer program.

Assessing the overall regression model. The initial step to find out that a logistic regression model, is an appropriate model, will first be seen in the suitability or suitability of the overall model. In the feasibility testing logistic regression model can be done by using the accuracy testing between the predictions of the logistic regression model with observational data. This test is needed to ensure there are no weaknesses to the conclusions from the model obtained. A good logistic regression model is if there is no difference between the observational data and the data obtained from the prediction results. Testing the absence of differences between predictions and observations was carried out by the Hosmer Lameshow test with the Chi square method approach. Thus if the test results are obtained that are not significant, it means there is no difference between the estimated logistic regression model data and the observation data. Table 2 presents Hosmer Lameshow test results of this study. The results of testing the similarity of the prediction model with observation obtained a chi square value of 11.562 with a significance of 0.172 . With a significance value greater than 0.05 , it means that there is no difference between the estimated logistic regression model data and the observation data. This means that the model is right with no need for model modification.

Table 2. Hosmer and Lemeshow Test Results

\begin{tabular}{cccc}
\hline Step & Chi-square & Df & Sig. \\
\hline 1 & 11.562 & 8 & 0.172 \\
\hline
\end{tabular}

Assessing the overall model (overall model fit). Testing the overall model in principle tests whether the use of three variables in this study can make the model better in explaining auditor shifts. In principle, testing with logistic regression as a whole is done by testing the change in the value of log likelihood in the model by using three independent variables that are hypothesized. The first step is to test the fit model without entering independent variables and only involving constants. Table 3 presents the results of testing the model fit stage one for this study and shows that comparison of the value of -2 log likehood done by comparing the value of -2 log likehood which only involves constants without entering an independent variable. The results of tests on the initial block (beginning block), namely the model only with constants, obtained an initial value of -2LL of 175.155.

Table 3. Model Fit Test Results for Phase 1

\begin{tabular}{|c|c|c|c|}
\hline Iteration & & -2 Log likelihood & Coefficients Constant \\
\hline \multirow{3}{*}{ Step 0} & 1 & 175.158 & 0.485 \\
\hline & 2 & 175.155 & 0.495 \\
\hline & 3 & 175.155 & 0.495 \\
\hline
\end{tabular}

a. Constant is included in the model.

b. Initial -2 Log Likelihood: 175.155

c. Estimation terminated at iteration number 3 because parameter estimates changed by less than .001 .

After testing the first stage model fit, the next step is testing the second stage model fit. Namely by including independent variables (tax minimization, tunneling incentives, and bonus mechanisms). Table 4 presents the results of the second stage fit model testing of this study. Based on the table 4, it can be seen in the initial block (beginning block) that is in the model only with constants, obtained a value of $-2 \log$ likelihood of 175.155 . In testing in block 1 or testing after entering all independent variables, the final log-likelihood (-2LL) value of 159.891 is obtained and there is significant decrease of $-2 \log$ likelihood after using 
3 independent variables. Thus the model with 3 independent shows as a better model or in other words the model is hypothesized fit with the data.

Table 4. Model Fit Test Results for Phase 2

\begin{tabular}{rrrrrrr}
\hline \multirow{2}{*}{ Iteration } & \multirow{2}{*}{-2 Log likelihood } & \multicolumn{5}{c}{ Coefficients } \\
\cline { 4 - 8 } & 1 & 160.420 & -1.017 & 3.309 & 0.017 & -0.337 \\
\multirow{3}{*}{ Step 1} & 2 & 159.894 & -1.189 & 4.175 & 0.019 & -0.398 \\
& 3 & 159.891 & -1.202 & 4.259 & 0.019 & -0.402 \\
& 4 & 159.891 & -1.202 & 4.260 & 0.019 & -0.402 \\
\hline
\end{tabular}

a. Method: Enter

b. Constant is included in the model.

c. Initial -2 Log Likelihood: 175.155

d. Estimation terminated at iteration number 4 because parameter estimates changed by less than .001 .

The next step is to test the omnibus test (overal model fit). Table 5 presents the results of the omnibus test (Overal Model Fit) which shows that chi square value of 15.264 has significance value of 0.002 . Thus the use of three independent variables can explain their effects on transfer pricing.

Tablel 5. Omnibus Test

\begin{tabular}{lcccc}
\hline & & Chi-square & Df & Sig. \\
\hline \multirow{3}{*}{ Step 1 } & Step & 15.264 & 3 & 0.002 \\
& Block & 15.264 & 3 & 0.002 \\
& Model & 15.264 & 3 & 0.002 \\
\hline
\end{tabular}

Coefficient of Determination (Nagelkerke $\mathbf{R}$ Square). The magnitude of the coefficient of determination in the logistic regression model is indicated by the value of Nagelkerke R Square. Table 6 presents result of Nagelkerke R Square test. The R Square value measured by Nagelkerke R Square is 0.149 which means that $14.9 \%$ of transfer pricing can be explained by the dependent variable, namely tax minimization, tuning inclusion and bonus mechanisms while the remaining $85.1 \%$ transfer pricing is influenced by other variables outside the research model.

Table 6, Determination Coefficient Test Results

\begin{tabular}{cccc}
\hline Step & -2 Log likelihood & Cox \& Snell R Square & Nagelkerke R Square \\
\hline 1 & $159.891^{\mathrm{a}}$ & 0.109 & 0.149 \\
\hline
\end{tabular}

a. Estimation terminated at iteration number 4 because parameter estimates changed by less than .001 .

Classification table. Table 7 shows that predictive power of the regression model to predict the probability of timeliness of financial reporting. The predictive power of the regression model to predict the likelihood that the dependent variable occurs is expressed in percent. Table 7 shows the predictive power of the regression model to predict the likelihood of a company doing transfer pricing is 72.0 percent. The result also shows that there are 28 companies $(44 \%)$ that are predicted to do transfer pricing from a total of 132 sample company data during the observation period (2015-2017) that carry out transfer pricing. The predictive power of the regression model to predict the likelihood of a company doing transfer pricing is 89.0 percent. This is that with the regression model, there are as many as 73 companies (89.0\%) that are predicted to do transfer pricing from a total of 132 sample company data during the observation period (2015-2017) that carry out transfer pricing. 
Table 7. Classification Tables

\begin{tabular}{llcccc}
\hline & & \multicolumn{3}{c}{ Predicted } \\
\cline { 3 - 4 } & & \multicolumn{2}{c}{ TPricing } & \multirow{2}{*}{ Percentage Correct } \\
\cline { 3 - 4 } & & 0.0000 & 1.0000 & \\
\hline \multirow{3}{*}{ Step 1 } & TPricing & 0.0000 & 22 & 28 & 44.0 \\
& & 1.0000 & 9 & 73 & 89.0 \\
& Overall Percentage & & & 72.0 \\
\hline
\end{tabular}

a. The cut value is .500

Logistic regression model. After getting a logistic regression model that is fit and does not require modification of the model, then hypothesis testing can be done. The results of hypothesis testing are done using partial test. Table 8 presents that partial independent variable testing by Wald test.

Table 8. Logistic regression test results

\begin{tabular}{llcccc}
\hline & & B & S.E. & Wald & Df \\
\hline \multirow{3}{*}{ Step $1^{\text {a }}$} & Tax & 4.260 & 1.612 & 6.981 & 1 \\
& Tunneling & 0.019 & 0.009 & 4.618 & 1 \\
& Bonus & -0.402 & 0.388 & 1.071 & 1 \\
& Constant & -1.202 & 0.672 & 3.197 & 1 \\
\hline
\end{tabular}

a. Variable(s) entered on step 1: Tax, Tunneling, Bonus

The form of the logistic regression equation is as follows:

$$
\text { Ln } \frac{T P}{1-T P}=1,202+4,260 \text { TAX }+0,019 \text { TUNNELING }-0,402 \text { BONUS }+\mathrm{e}
$$

The equation can be explained as follows:

1. The value of the coefficient of the constant variable in the logistic regression equation is 1,202 , this states that without tax minimization, tunneling incentive, and bonus mechanisms, companies are less likely to transfer pricing.

2. The value of the variable coefficient of the tax minimization variable is obtained at 4.260. The direction of the positive coefficient means that companies that pay greater taxes tend to do transfer pricing.

3. The value of the variable coefficient of the Tuning variable incentives is 0.019 . The direction of the positive coefficient means that for companies that have a greater incentive, then the probability of the company will tend to do transfer pricing.

4. The value of the coefficient of the bonus mechanism variable coefficient is equal to 0.402. The direction of the negative coefficient means that for companies that have a larger bonus scheme, the company tends not to do transfer pricing.

The relationship between tax minimization to transfer pricing decisions. Table 9 shows that first hypothesis $\left(\mathrm{H}_{1}\right)$ which states that Tax minimization affects the transfer pricing decision turns out to be accepted, so the tax minimization variable measured using the ETR formula with a significance of $0.008<0.05$, the tax minimization variable has a significant effect on the company's decision to make transfers pricing. This research is in line with Hartati and Julita (2015), which explains that the magnitude of the decision to conduct transfer pricing practices will result in tax payments being lower globally in general. This is because multinational companies that benefit will shift revenue from countries with high tax rates to countries with low tax rates, so the higher the tax rate of a country, the more likely the company is to practice transfer pricing. 
Table 9. Logistic regression test results

\begin{tabular}{llcccc}
\hline & & B & S.E. & Df & Sig. \\
\hline \multirow{3}{*}{ Step $1^{\text {a }}$} & Tax & 4.260 & 1.612 & 1 & 0.008 \\
& Tunneling & 0.019 & 0.009 & 1 & 0.032 \\
& Bonus & -0.402 & 0.388 & 1 & 0.301 \\
& Constant & -1.202 & 0.672 & 1 & 0.074 \\
\hline
\end{tabular}

a. Variable(s) entered on step 1: Tax, Tunneling, Bonus

The relationship between tunneling incentive to transfer pricing decisions. Table 9 shows that second hypothesis $\left(\mathrm{H}_{2}\right)$ which states that Tunneling incentive influences the transfer pricing decision turns out to be accepted so that the tunneling incentive variable has a significant effect on the transfer pricing decision. With a significance value of significance of $0.032<0.05$, tunneling incentive has a significant effect on the probability of a company conducting transfer pricing. The results of this study support Hartati and Julita (2015), which states that related party transactions are more commonly used to transfer wealth to majority shareholders rather than dividend payments, because companies must distribute dividends to parent companies and other minority shareholders. Yuniasih et al., (2012) states that the unique conditions in which share ownership in Indonesian public companies tend to be concentrated, so there is a tendency of the majority shareholders to the tunnel.

The relationship between bonus mechanism to transfer pricing decision. Table 9 shows that third hypothesis $\left(\mathrm{H}_{3}\right)$ which states the bonus mechanism influences the transfer pricing decision turned out to be rejected so that the company's bonus mechanism variable does not have a significant effect on transfer pricing. It can be seen the significance value of 0.301> 0.05. This is because the ratio of the company's profit increase is quite high, but the company that experienced an increase in profit is not indicated to conduct transfer pricing transactions. This research is in line with Mispiyanti (2015). However, this study is not in line with Hartati and Julita (2015) which states that the owner of the company will see the company's profits generated as a whole as an assessment for the performance of its directors so that the directors will try as much as possible so that overall company profits have increased including by way of transfer pricing.

\section{CONCLUSION}

Tax minimization and tunneling incentives have a significant effect on transfer pricing decisions while the company's bonus mechanism does not have a significant effect on transfer pricing. This research is expected to provide an overview and a referencein making policies regarding transfer pricing, specificallypreventive policies so that companies do not do irregularities in carrying out transfer pricing practices. This research is expected to provide input regarding taxminimization, bonus mechanism, tunneling incentive to the decision to make transfer pricing so assist them in making decisions and being aware the importance of business ethics. Furthermore, it can contribute to the development of management accounting and provide insight and additional information for the reader regarding what factors are affecting the company's decision to transfer pricing.

Future research is expected to present results higher quality research with some input regarding some things including: (1) extend or expand research period so that it can produce research results andmore accurate conclusions that illustrate the effect of taxminimization, bonus mechanism, tunneling incentive regarding the decision to transfer pricing; (2) add other factors inthe decision to transfer pricing, such as tax budget and tax director; and (3) compare two or moreindustrial sector. This is to find out which industry sectorwho do the most transfer pricing and find outwhat is the most influential factor in each industry sector inmake transfer pricing decisions. 


\section{REFERENCES}

Badan Pelatihan Pendidikan Keuangan. (2011). Hubungan istimewa konversi hutang menjadi modal: Kasus pengadilan. http://www.bppk.kemenkeu.go.id/berita-pajak/12261transaksi-hubungan-istimewa.

Fathoni, A. (2015). Fungsi \& jenis-jenis pajak. http://www.zonasiswa.com/2015/01/fungsijenis-jenis-pajak.

Gusnardi. (2009). Penetapan harga transfer dalam kajian perpajakan. Journal Pendidikan Ekonomi dan Bisnis, $1(1), \quad 36-43$. https://pekbis.ejournal.unri.ac.id/index.php/JPEB/article/view/365

Hartati, W., Desmiyawati, \& Azlina, N. (2014). Analisis pengaruh pajak dan mekanisme bonus terhadap keputusan transfer pricing. Studi empiris pada seluruh perusahaan yang listing di Bursa Efek Indonesia. Prosiding SNA 17 Mataram. https://www.coursehero.com/file/17845048/047

Hartati, W., \& Julita, D. (2015). Tax minimization, tunneling incentive dan mekanisme bonus terhadap keputusan transfer pricing. Studi empiris pada seluruh perusahaan yang listing di Bursa Efek Indonesia.Prosiding SNA 18 Medan. https://akuntansia.com/jurnal-akuntansi-tentang-pajak-dan-transfer-pricing.

Lubis, A. I. (2010). Akuntansi keperilakuan. Jakarta: Salemba Empat.

Mangoting, Y. (2000). Aspek perpajakan dalam praktek transfer pricing. Jurnal Akuntansi dan Keuangan Indonesia, 69-82. http://jurnalakuntansi.petra.ac.id/index.php/aku/article/view/15668

Marfuah, M., \& Azizah, A. P. N. (2014). Pengaruh pajak, tunneling incentive dan exchange rate terhadap keputusan transfer pricing. Jurnal Akuntansi Dan Auditing Indonesia, 18(2), 156-165. https://doi.org/10.20885/jaai.vol18.iss2.art6

Mispiyanti. (2015). Pengaruh pajak, tunneling incentive, dan mekanisme bonus terhadap keputusan transfer pricing. Jurnal of Accounting And Investment, 16(1), 62-73. https://journal.umy.ac.id/index.php/ai/article/view/1348

Mutamimah. (2009). Tunneling atauvalue added dalam strategi merger dan akuisisi di Indonesia. Jurnal Manajemen Teori dan Terapan, 2(2), 161-182. https://ejournal.unair.ac.id/JMTT/article/view/2382

Santoso, I. (2004). Advance pricing agreement dan problematika transfer pricing dari perspektif perpajakan Indonesia. Jurnal Akuntansi dan Keuangan, 6(2), 123-139. http://jurnalakuntansi.petra.ac.id/index.php/aku/article/view/16158

Utomo, S. (2011). Skema bonus dewan direksi dan aktivitas manjamen laba (Penelitian pada perusahaan manufaktur di BEI). Jurnal Dinamika Ekonomi dan Bisnis, 8(1), 93-104. https://ejournal.unisnu.ac.id/JDEB/article/view/103

Undang-Undang Nomor 36 tahun 2008 tentang Pajak Penghasilan.

Wiranata, Y. A., \& Nugrahanti, Y. W. (2013). Pengaruh struktur kepemilikan terhadap profitabilitas perusahaan manufaktur di Indonesia. Jurnal Akuntansi dan Keuangan, 15(1), 15-26. https://ejournal.unisnu.ac.id/JDEB/article/view/103

Yuniasih, N. W., Rasmini, N. K., \& Wirakusuma, M. G. (2012). Pengaruh pajak dan tunneling incentive pada keputusan transfer pricing perusahaan manufaktur yang listing di Bursa Efek Indonesia. Prosiding SNA 15 Banjarmasin. http://pdeb.fe.ui.ac.id/?p=6696 